\title{
Analisis Variasi Kecepatan Geser Pengelasan Terhadap Nilai Kekerasan dan Uji Tarik Pada Las MIG Otomatis
}

\author{
Rizal Cahyadiatma ${ }^{1}$, Solichin $^{2}$, Duwi Leksono Edy ${ }^{3}$ \\ ${ }^{123}$ Program Studi S1 Pendidikan Teknik Mesin Jurusan Teknik Mesin \\ ${ }^{123}$ Fakultas Teknik Universitas Negeri Malang \\ 1,2,3 Jalan Semarang No. 5, Malang 65145 \\ E-mail: rizalcahyadiatma@gmail.com ${ }^{1}$
}

\begin{abstract}
Abstrak: Penelitian ini bertujuan untuk mengetahui nilai kekuatan tarik dan kekerasan vickers sambungan las dari perbedaan kecepatan geser elektroda sebesar $3 \mathrm{~mm} / \mathrm{s}, 5 \mathrm{~mm} / \mathrm{s}$, dan $7 \mathrm{~mm} / \mathrm{s}$. Metode yang digunakan adalah eksperimen dengan desain penelitian pre experimental design. Jenis analisis data yang digunakan adalah teknik analisis deskriptif. Adapun hasil dari penelitian ini menunjukkan peningkatan nilai kekuatan tarik dan penurunan nilai kekerasan pada kecepatan geser elektroda yang relatif rendah. Berdasarkan nilai rata-rata hasil pengujian tarik dan kekerasan vickers, kecepatan geser elektroda $3 \mathrm{~mm} / \mathrm{s}$ menghasilkan nilai kekerasan vickers sebesar 136,7 HVN dan nilai kekuatan tarik sebesar $61,19 \mathrm{Kgf} / \mathrm{mm}^{2}$. Kecepatan geser elektroda $5 \mathrm{~mm} / \mathrm{s}$ menghasilkan nilai kekerasan vickers sebesar 119,2 HVN dan nilai kekuatan tarik sebesar $60,62 \mathrm{Kgf} / \mathrm{mm}^{2}$.. Kecepatan geser elektroda $7 \mathrm{~mm} / \mathrm{s}$ menghasilkan nilai kekerasan vickers sebesar 170,7 HVN dan nilai kekuatan tarik sebesar $54,96 \mathrm{Kgf} / \mathrm{mm}^{2}$.
\end{abstract}

Kata kunci: pengelasan MIG, kekerasan vickers, kekuatan tarik.

\begin{abstract}
This study aims to determine the value of the tensile strength and hardness of the weld joint vickers of the electrode shear velocity differences of $3 \mathrm{~mm} / \mathrm{s}, 5 \mathrm{~mm} / \mathrm{s}$, and $7 \mathrm{~mm} / \mathrm{s}$. The method used is an experiment with a pre experimental design research design. The type of data analysis used is descriptive analysis technique. The results of this study indicate an increase in the value of tensile strength and a decrease in the value of hardness at the relatively low electrode shear velocity. Based on the average value of the tensile and hardness test results of vickers, the electrode shear velocity of $3 \mathrm{~mm} / \mathrm{s}$ produces a vickers hardness value of $136.7 \mathrm{HVN}$ and a tensile strength value of $61.19 \mathrm{Kgf} / \mathrm{mm} 2$. Electrode shear velocity of $5 \mathrm{~mm} / \mathrm{s}$ produces a vickers hardness value of $119.2 \mathrm{HVN}$ and a tensile strength value of 60.62 $\mathrm{Kgf} / \mathrm{mm} 2$.. Electrode shear velocity of $7 \mathrm{~mm} / \mathrm{s}$ produces a vickers hardness value of $170.7 \mathrm{HVN}$ and a tensile strength value of $54.96 \mathrm{Kgf} / \mathrm{mm} 2$..
\end{abstract}

Keywords: MIG welding, vickers hardness, tensile strength.

Salah satu teknologi yang sudah dipergunakan dengan baik adalah teknik pengelasan untuk menyambung logamlogam pada konstruksi bangunan seperti baja dan mesin. Dengan contoh pembuatan mesin dan bangunan yang dibuat menggunakan teknik pengelasan akan membuat proses lebih ringan dan efisien. Oleh karena itu membuat produksi pembuatan menjadi murah dan pengelasan lebih sering digunakan. Pengelasan merupakan proses untuk menggabungkan logam dimana logam menjadi bersatu akibat panas las, dimana bisa atau tidak adanya pengaruh tekanan, dan bisa atau tidak adanya logam pengisi. Menurut pengertian dari Duetch Industrie Normen (DIN) las adalah ikatan metalurgi yang terdapat di sambungan logam atau logam paduan yang dilaksanakan dalam keadaan lumer atau cair. Dari pengertian tersebut dapat disimpulkan lebih lanjut bahwa las adalah proses menyambung dari satu atau lebih batang logam yang menggunakan energi panas (Wiryosumarto, 2000).

Penggunaan elektroda pada pengelasan MIG (Metal Inert Gas) berbentuk kawat las yang merupakan las busur gas. Motor listrik digunakan untuk mengatur gerakan elektroda yang berupa gulungan kawat. Las metode ini menggunakan gas sebagai pelindung pada saat busur dan logam yang mencair dari pengaruh lingkungan. Pengaplikasian las MIG (Metal Inert Gas) biasanya diaplikasikan untuk pengelasan di industri yang membuat suatu alat ataupun barang. Sebagai contoh pada pembuatan pesawat terbang, rangka mobil, pagar rumah dan masih banyak lagi. Penggunaan pengelasan juga sering dugunakan dalam berbagai industry dikarenakan berbagai hal diantaranya efisien, ekonomis, dan praktis. Keuntungan penggunaan las MIG misalnya pada las ini tidak menghasilkan terak layaknya las SMAW (Shield Metal Arc Welding). Oleh karena itu las MIG (Metal Inert Gas) ini juga menambah nilai efisiensi.

Pada proses pengelasan MIG (Metal Inert Gas) juga harus diperhatikan kecepatan geser elektroda untuk mendapatkan hasil lasan yang baik karena laju pengelasan berpengaruh terhadap hasil las secara visual maupun secara pengujian di laboratorium. Singh (2012: 13) menyatakan bahwa parameter penting dalam sebuah pengelasan merupakan kecepatan 
pengelasan, arus pengelasan, tegangan busur dan medan magnet eksternal. Kecepatan geser pengelasan bergantung pada parameter pengelasan yang lainnya seperti kuat arus, jenis elektroda, diameter inti elektroda, logam yang akan dilas, jenis sambungan dan lain sebagainya. Dalam pengelasan, kecepatan geser elektroda tinggi menghasilkan kurangnya penetrasi las, kurangnya kekuatan sambungan dan menyebabkan logam las menerima energi masukan panas dengan jumlah yang kecil. Oleh karena itu kecepatan geser elektroda bisa merubah sifat mekanik hasil lasan seperti nilai tegangan tarik sambungan dan kekerasan.

\section{METODE}

Jenis penelitian yang digunakan adalah eksperimen dengan desain penelitian pre eksperimental design. Tujuan dari penelitian ini adalah untuk mengetahui nilai tegangan tarik dan kekerasan vickers sambungan las dengan kecepatan pengelasan $3 \mathrm{~mm} / \mathrm{s}, 5 \mathrm{~mm} / \mathrm{s}$ dan $7 \mathrm{~mm} / \mathrm{s}$. Data yang diperoleh dari penelitan ini berbentuk angka-angka hasil pengujian yang berasal dari pengujian laboraturium. Data tersebut akan dideskripsikan secara naratif sehingga membentuk kesimpulan hasil penelitian.

Sampel penelitian adalah sambungan hasil pengelasan MIG. Material yang digunakan pada proses pengelasan MIG adalah baja karbon S50C dimana pada material ini memiliki kadar karbon sebesar 0,50 \%. Elektroda yang digunakan adalah jenis elektroda copper coated mig wire dengan seri AWS A5.18 ER70S-6. Posisi pengelasan yang digunakan adalah posisi down hand (1G) Sedangkan kampuh yang digunakan adalah kampuh V dengan sudut 600 dan jarak root face $2 \mathrm{~mm}$ serta jarak antar kampuh $2 \mathrm{~mm}$.

Spesimen yang digunakan untuk pengujian tarik sebanyak 9 spesimen uji per perlakuan sedangkan pengujian vickers dilakukan sebanyak 3 titik per spesimen uji. Standar uji tarik yang digunakan adalah ASTM E8/E8 M-09 dan standar uji vickers yang digunakan adalah ASTM E92-82. Adapun pada standar uji vickers tidak ada karakteristik bentuk spesimen uji sehingga bentuk spesimen uji yang digunakan untuk pengujian vickers berbentuk hampir sama dengan pengujian tarik. Pengujian kekerasan vickers dilakukan pada daerah lHAZ. Sedangkan untuk spesimen pengujian tarik sesuai dengan standar ASTM E8/E8 M-09. Adapun spesimen pengujian tarik sebagai berikut.

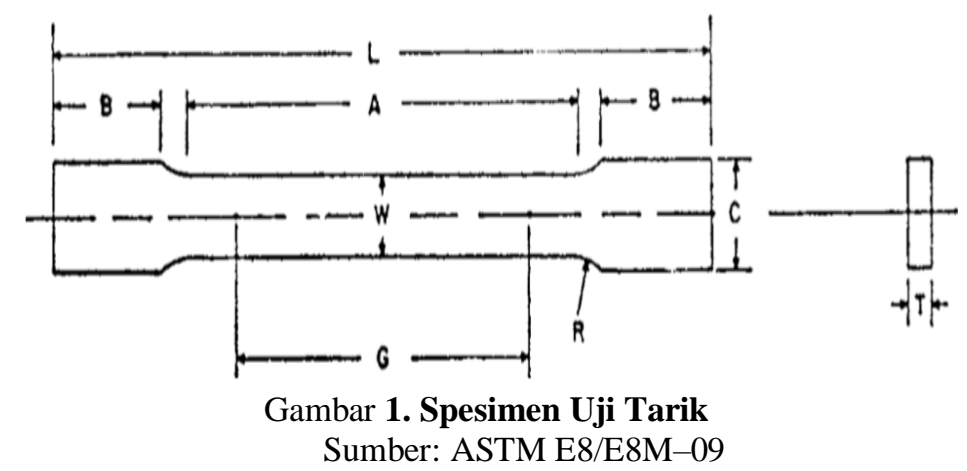

Tabel 1. Dimensi Spesimen Uji Tarik

\begin{tabular}{ll}
\hline \multicolumn{2}{c}{ Standard Specimens Sheet-Type, $12.5 \mathrm{~mm}$} \\
\hline \multicolumn{1}{c}{ Type } & \multicolumn{1}{c}{ Dimention } \\
\hline G - Gage Langht & 50 \\
W - Width & 12,5 \\
T - Thickness & - \\
R - Radius of fillet, min. & 12,5 \\
L - Overall lenght & 200 \\
A - Lenght of reduced section, min & 57 \\
B - Lenght of grip section, min & 50 \\
C - Widht of grip section, approximate & 20 \\
\hline
\end{tabular}

Sumber: ASTM E8/E8M-09

Sedangkan untuk bentuk spesimen uji kekerasan vickers mengacu pada standar ASTM E92-82. Berdasarkan standar ASTM E92-82 bahwa untuk bentuk dan ukuran spesimen uji menyesuaikan mesin atau alat uji vickers. oleh karena itu bentuk spesimen uji vickers pada penelitian ini sebagai berikut. 


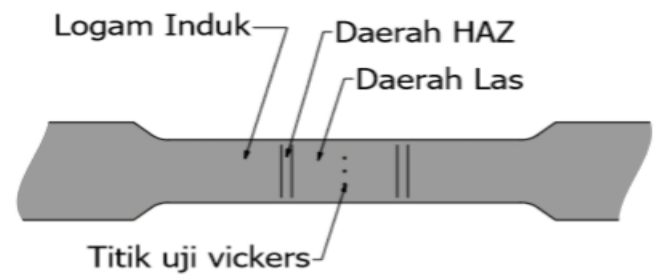

Gambar 2. Spesimen Uji Vickers

Sumber: ASTM E92-82

Titik pengujian kekerasan vickers diambil pada bagian daerah HAZ sebanyak 3 (tiga) titik di setiap spesimen. Pengambilan data dimulai dari pemotongan sampel dengan ukuran 100x120 (mm) selanjutnya dibentuk kampuh V dengan sudut 600 dengan jarak root face $2 \mathrm{~mm}$. Kemudian atur parameter pengelasan terkait jenis elekroda dan kecepatan pengelasan. Setelah itu, sampel yang sudah jadi dijepit di meja las untuk mengurangi deformasi kemudian di las tack weld. Setelah pengelasan tack weld dan melakukan pengelasan dengan gerak $1 \mathrm{G}$ atau downhand. Setelah pengelasan pada sampel penelitian hasil sampel yang dilas didiamkan dalam suhu ruangan kemudian dipotong sesuai bentuk spesimen uji. Pembentukan spesimen uji menggunakan proses machining. Setelah spesimen terbentuk kemudian dilakukan pengujian vickers dan pengujian tarik. Pada akhir kegiatan penelitian keluar data pengujian kemudian dideskripsikan secara naratif.

\section{PEMBAHASAN}

\section{Kecepatan Pengelasan}

Proses pengelasan pada penelitian ini membutuhkan 8 lapis setiap variasi kecepatan agar kampuh benar-benar terisi oleh kawat las. Penelitian ini menentukan kecepatan pengelasan yang dilakukan dengan variasi sebesar $3 \mathrm{~mm} / \mathrm{s}, 5 \mathrm{~mm} / \mathrm{s}$, dan 7 $\mathrm{mm} / \mathrm{s}$.

\section{Kekuatan Tarik}

Berdasarkan hasil penelitian sambungan las pada baja karbon S50C dengan kecepatan pengelasan $3 \mathrm{~mm} / \mathrm{s}, 5 \mathrm{~mm} / \mathrm{s}$ dan $7 \mathrm{~mm} / \mathrm{s}$ diperoleh hasil pengujian tarik sebagai berikut

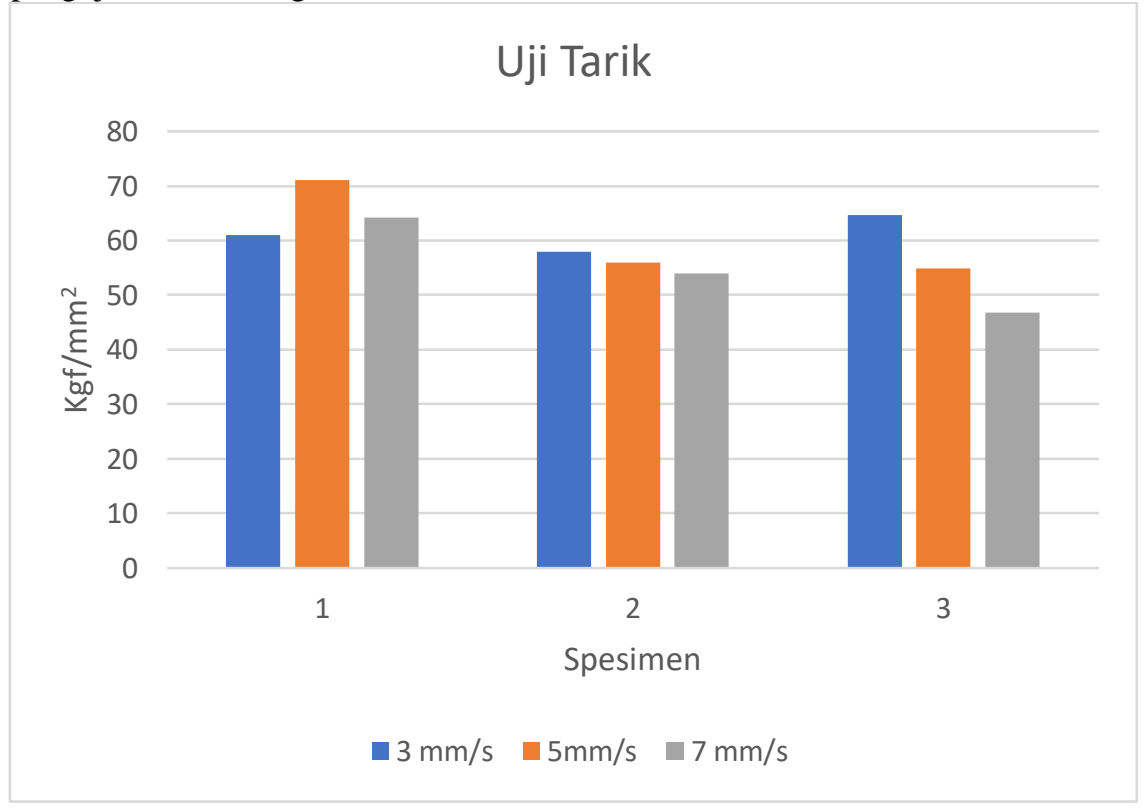

Gambar 3. Hasil Uji Tarik

Dari Gambar 3 dapat dilihat hasil data uji tarik menunjukkan terdapat penuruan pada nilai uji tarik jika kecepatan geser ditingkatkan. Hasil rata-rata dari tiga specimen uji dengan kecepatan geser elektroda $3 \mathrm{~mm} / \mathrm{s}$ sebesar $61,19 \mathrm{Kgf} / \mathrm{mm} 2$, sedangkan untuk kecepatan geser elektroda $5 \mathrm{~mm} / \mathrm{s}$ sebesar $60,62 \mathrm{Kgf} / \mathrm{mm} 2$, dan untuk kecepatan geser elektroda $7 \mathrm{~mm} / \mathrm{s}$ sebesar 54,96 Kgf/mm2. Hal itu dapat disimpulkan bahwa peningkatan kecepatan geser elektroda pada proses pengelasan cenderung menurunkan nilai uji tarik.

Ditinjau dari jenis elektroda, ampere, proses pendinginan setelah pengelasan semua sampel memperoleh treatment yang sama. Bahwa temperatur dan waktu penahanan terhadap panas dapat menaikkan nilai kekuatan tarik dan kekerasan suatu 
bahan (Wardoyo: 237). Jika ditinjau dari teori tersebut proses pengelasan ini juga sejalan dengan teori yang dipaparkan. Pada kecepatan geser elektroda rendah $(3 \mathrm{~mm} / \mathrm{s})$ panas yang diterima material dari elektroda akan relatif lama karena kecepatan geser elektroda rendah sehingga panas yang tertahan pada material akan meningkat. Hal tersebut akan mengakibatkan naiknya nilai kekuatan tarik pada sambungan las. Berdasarkan teori tersebut, hasil kekuatan tarik pada penelitian ini menunjukkan adanya peningkatan apabila kecepatan geser elektroda diperkecil. Sejalan dengan penelitian ini, Mohruni, dkk pada tahun 2013, penelitian tersebut menunjukkan bahwa kecepatan geser elektroda atau kecepatan pengelasan mempengaruhi hasil pengujian tarik. Semakin rendah tingkat kecepatan pada proses pengelasan mengakibatkan peningkatan pada nilai uji tarik.

\section{Kekerasan Vickers}

Berdasarkan hasil penelitian sambungan las pada baja karbon S50C dengan kecepatan pengelasan $3 \mathrm{~mm} / \mathrm{s}, 5 \mathrm{~mm} / \mathrm{s}$ dan $7 \mathrm{~mm} / \mathrm{s}$ diperoleh hasil pengujian kekerasan vickers sebagai berikut.

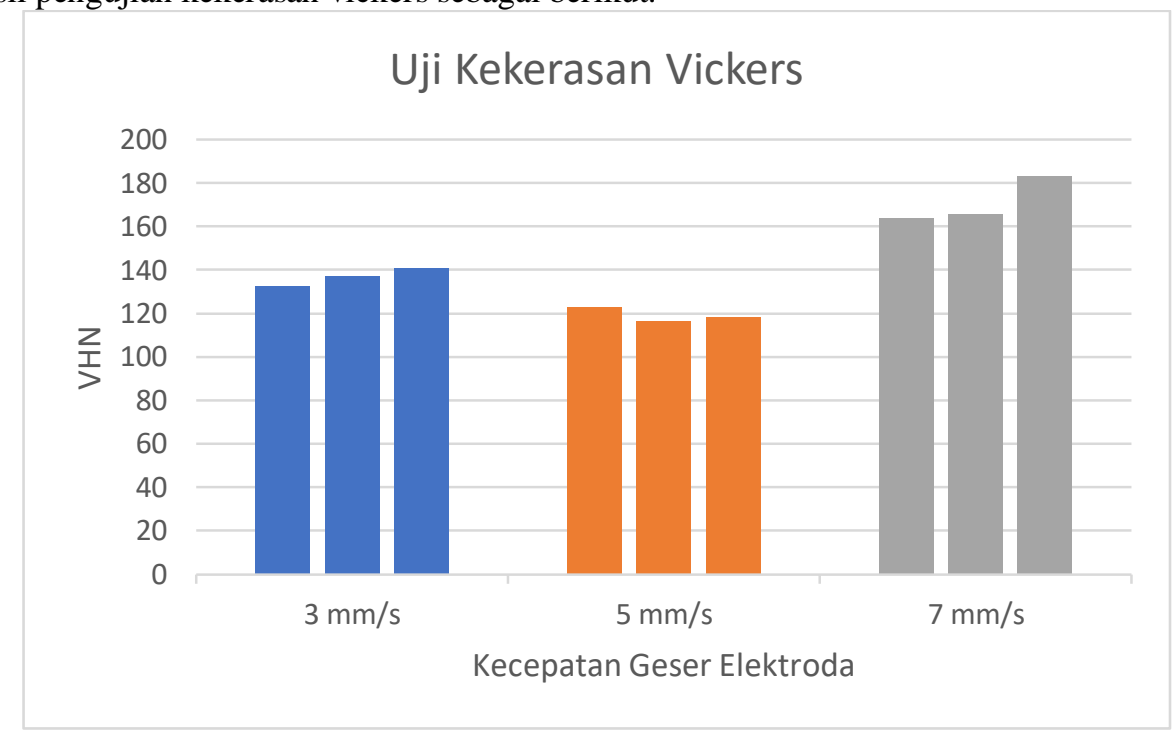

Gambar 4. Hasil Uji Vickers

Jika dilihat dari hasil Gambar 4 Hasil data uji kekerasan vickers menunjukkan terdapat peningkatan pada nilai uji kekerasan vickers jika kecepatan geser ditingkatkan. Hasil rata-rata dari tiga specimen uji dengan kecepatan geser elektroda 3 $\mathrm{mm} / \mathrm{s}$ sebesar 136,7 HVN, sedangkan untuk kecepatan geser elektroda $5 \mathrm{~mm} / \mathrm{s}$ sebesar 119,2 HVN, dan untuk kecepatan geser elektroda $7 \mathrm{~mm} / \mathrm{s}$ sebesar 170,7 HVN. Hal itu dapat disimpulkan bahwa peningkatan kecepatan geser elektroda pada proses pengelasan cenderung meningkatkan nilai uji kekerasan vickers.

Setiap proses pengelasan dengan variasi kecepatan mengalami kenaikan kekerasan di daerah logam induk dan daerah lasan. Hal tersebut sesuai dengan teori bahwa nilai kekerasan akan cenderung semakin kecil bila kecepatan semakin lambat. Namun hal tersebut berbeda jika kekerasan di uji di daerah HAZ (Heat Affected Zone). Kekerasan material jika diuji didaerah HAZ akan cenderung lebih tinggi daripada daerah logam induk dan daerah lasan dikarenakan adanya panas yang masuk dan diikuti laju pendinginan yang cepat (Suprijanto, 2005). Penelitian yang menghubungkan kecepatan pengelasan dan heat input menunjukan bahwa semakin rendahnya kecepatan pengelasan akan memperbesar heat input dan akan membuat logam semakin lunak dan HVN semakin kecil begitupun sebaliknya (Jufri, 2016).

Berdasarkan teori tersebut, hasil kekerasan vickers pada penelitian ini menunjukkan adanya peningkatan apabila kecepatan geser elektroda diperbesar. Sejalan dengan penelitian ini, Jufri, dkk pada tahun 2016, penelitian tersebut menunjukkan bahwa kecepatan geser elektroda atau kecepatan pengelasan mempengaruhi hasil kekerasan vickers . Semakin tinggi tingkat kecepatan pada proses pengelasan mengakibatkan peningkatan pada nilai kekerasan vickers.

\section{Hubungan Antara Kecepatan Geser Elektroda Terhadap Kekuatan Tarik dan Kekerasan Vickers}

Berdasarkan hasil penelitian ini, dapat disimpulkan tentang tingkat kekerasan dari penelitian ini yang juga sejalan dengan penelitian-penelitian terdahulu bahwa kecepatan geser elektroda yang relatif cepat akan meningkatkan nilai kekerasan vickers. Hal tersebut dikarenakan jika kecepatan geser elektroda cepat akan mengakibatkan nilai energi masukan panas (heat input) menjadi kecil. Jika energi masukan panas (heat input) kecil akan membuat laju pendinginan logam akan menjadi cepat. Dengan laju pendinginan yang cepat akan membuat logam menjadi keras sehingga nilai kekerasan akan cenderung tinggi.

Begitu pula sebaliknya jika kecepatan geser elektroda relatif lambat akan membuat energi masukan panas (heat input) yang diterima logam akan semakin besar. Hal tersebut mengakibatkan laju pendinginan akan semakin lama sehingga logam menjadi lebih lunak. Hal tersebut berarti bahwa jika logam menjadi lunak maka nilai kekerasan cenderung kecil. Dengan 
kecepatan geser elektroda yang lambat juga mengakibatkan melebarnya daerah HAZ (Heat Affected Zone). Hal tersebut dikarenakan penyebaran energi masukan panas yang masuk pada logam akan lebih lama.

Dapat disimpulkan tentang tingkat uji tarik dari penelitian ini juga sejalan dengan penelitian-penelitian diatas bahwa kecepatan geser elektroda yang relatif lambat akan meningkatkan nilai uji tarik. Hal tersebut dikarenakan jika kecepatan geser elektroda relatif lambat maka panas yang tertahan pada logam juga akan meningkat. Hal tersebut mengakibatkan daya ikat antar butiran logam cenderung menurun sehingga nilai uji tarik akan cenderung tinggi

Begitu pula sebaliknya jika kecepatan geser elektroda yang relatif cepat akan menurunkan nilai uji tarik. Hal tersebut dikarenakan jika kecepatan geser elektroda relatif cepat aka panas yang tertahan pada logam juga akan menurun. Hal tersebut mengakibatka daya ikat antar butiran logam cenderung meningkat sehingga nilai uji tarik akan cenderung rendah.।

Berdasarkan pada penelitian ini, kecepatan geser elektroda dapat mempengaruhi nilai kekuatan tarik dan kekerasan vickers pada hasil proses pengelasan. Hasil data penelitian ini menunjukkan bahwa kecepatan geser elektroda yang relatif cepat pada proses pengelasan dapat menurunkan nilai kekuatan tarik namun sebaliknya dapat menaikkan nilai kekerasan. Jika kecepatan geser elektroda relatif lambat maka akan menaikkan nilai kekuatan tarik dan menurunkan nilai kekerasan pada hasil las. Dapat disimpulkan bahwa kecepatan geser elektroda dapat mempengaruhi hasil lasan secara signifikan.

Adapun perbedaan nilai yang terjadi pada kekuataan tarik kecepatan rendah $3 \mathrm{~mm} / \mathrm{s}$ dengan kecepatan tinggi $7 \mathrm{~mm} / \mathrm{s}$ sebesar $6,23 \mathrm{Kgf} / \mathrm{mm} 2$, sedangkan untuk perbedaan nilai kekerasan vickers pada kecepatan rendah $3 \mathrm{~mm} / \mathrm{s}$ dengan kecepatan tinggi $7 \mathrm{~mm} / \mathrm{s}$ sebesar $34 \mathrm{VHN}$.

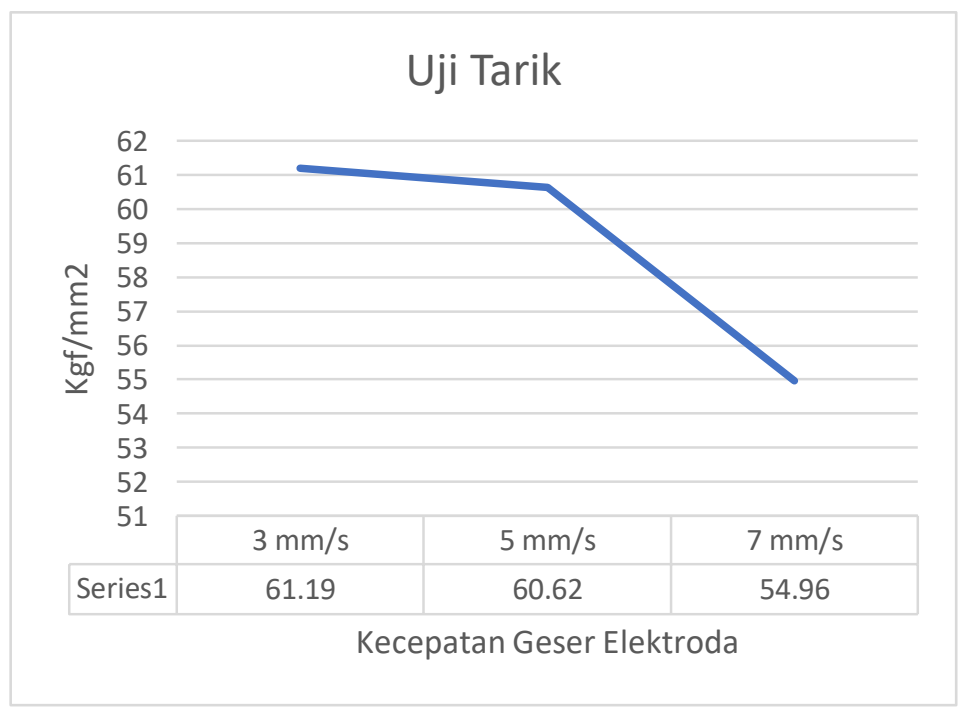

Gambar 5 Grafik Rata-rata Uji Tarik

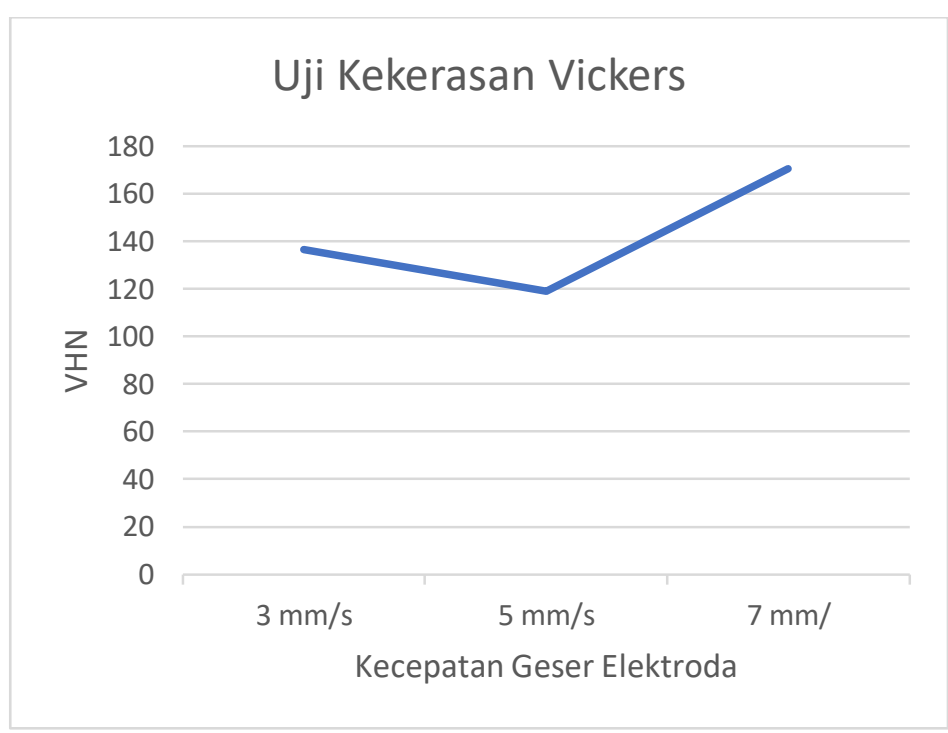

Gambar 6 Grafik Rata-rata Uji Kekerasan Vickers 
Berdasarkan gambar grafik pada Gambar 5 dengan Gambar 6 maka dapat dideskripsikan bahwa nilai kekuatan tarik berbanding terbalik dengan nilai kekerasan vickers. Jika kecepatan geser elektroda tinggi maka grafik uji tarik akan menunjukkan semakin ke bawah dimana memiliki arti bahwa nilai kekuatan tarik semakin rendah. Sedangkan jika kecepatan geser elektroda tinggi maka grafik uji kekerasan vickers akan meninjukkan semakin ke atas dimana memiliki arti bahwa nilai kekerasan vickers semakin tinggi. Kedua sifat mekanik tersebut yaitu kekuatan tarik dan kekerasan ada untuk memberikan kekuatan pada suatu material. Jika ditinjau dari proses pengujiannya uji kekerasan diuji hanya pada permukaan materialnya saja. Sedangkan untuk uji tarik material akan ditarik hingga putus sehingga pengujian ini melibatkan seluruh unsur material. Dapat disimpulkan bahwa uji kekerasan menguji kekuatan bagian luarnya saja sedangkan uji tarik menguji kekuatan seluruh bagian material.

\section{PENUTUP \\ Simpulan}

Kecepatan geser memberikan pengaruh terhadap nilai kekuatan tarik dan kekerasan hasil sambungan las. Hasil uji kekuatan tarik pada penelitian ini menunjukkan adanya peningkatan nilai uji kekuatan tarik jika kecepatan geser elektroda rendah, begitu juga sebaliknya jika kecepatan geser elektroda tinggi nilai uji kekuatan tarik menunjukkan adanya penurunan. Adapun nilai hasil pengujian tarik tertinggi sebesar $61,19 \mathrm{Kgf} / \mathrm{mm} 2$ yang diperoleh dari kecepatan geser elektroda $3 \mathrm{~mm} / \mathrm{s}$. Hal itu sejalan dengan kajian teori bahwa peningkatan nilai kekuatan tarik pada sambungan las terjadi karena panas yang diterima oleh material merata. Panas yang diterima material disebabkan oleh kecepatan geser elektroda. Maka dapat dikatakan bahwa kecepatan geser elektroda mempengaruhi nilai kekuatan tarik sambungan las.

Hasil uji kekerasan vickers daerah HAZ pada penelitian ini menunjukkan bahwa adanya peningkatan nilai uji kekerasan vickers jika kecepatan geser elektroda tinggi, begitu juga sebaliknya jika kecepatan geser elektroda rendah nilai nilai uji kekerasan vickers menunjukkan adanya penurunan. Adapun nilai nilai uji kekerasan vickers tertinggi sebesar 170,7 VHN yang diperoleh dari kecepatan geser elektroda $7 \mathrm{~mm} / \mathrm{s}$.

\section{Saran}

Khususnya bagi industri disarankan untuk memberikan perhatian lebih terhadap parameter pengelasan salah satunya yaitu pada faktor kecepatan geser elektroda pengelasan karena parameter pengelasan memiliki pengaruh yang signifikan terhadap hasil sambungan las. Bagi lembaga pendidikan diharapkan mampu memberikan pengertian lebih terhadap peserta didik tentang pentingnya parameter pengelasan. Hal tersebut dapat dilakukan dengan cara menjadikan parameter pengelasan sebagai instrumen pembelajaran agar peserta didik mendapatkan pengetahuan dan keterampilan yang baik dan menghasilkan lulusan yang siap kerja di dunia industri manufaktur. Bagi peneliti yang akan meneliti tentang pengelasan: (1) dapat mengembangkan hasil penelitian ini dengan memberikan variabel penelitian yang lebih variatif sehingga hasil penelitian lebih unik; (2) diperlukan lebih lanjut untuk mengetahui nilai impact dan hubungan antara nilai impact dengan kekuatan tarik pada sambungan las. Selain itu, peneliti selanjutnya disarakan untuk merencanakan segala sesuatunya dengan terstruktur baik teknis maupun non teknis.

\section{DAFTAR RUJUKAN}

ASTM International (E8-8M-09). 2010. Standart Test Methods for Tension Testing of Metalic Materials. United States of America.

ASTM International (E92-82). 1997. Standart Test Methods for Vickers Hardness Metalic Materials. United States of America.

AWS Committee on Structural Welding. 2000. AWS D1.1: Structural Welding Code-Steel. American Welding Society: United States of America

Jensen, A., Chenoweth, H. H. 1991. Kekuatan Bahan Terapan. Terjemahan Darwin Sabayang. Jakarta: Erlangga. 1983

Jufri, M., Subekti, N., \& Asfat, A. 2017. Efek Kecepatan Pengelasan Terhadap Sifat Baja Mekanik Hasil Pengelasan FCAW pada Plat Baja A36.

Mohruni, A. S., \& Kembaren, B. H. 2013. Pengaruh Variasi Kecepatan dan Kuat Arus Terhadap Kekerasan, Tegangan Tarik, Struktur Mikro Baja Karbon Rendah dengan Elektroda E6013. Jurnal Teknik Mesin. 13(1), 1-7.

Muslim, M. J., Fahmi, A. H., \& Hidayat, A. 2015. Studi Eksperimental Pengaruh Tembaga Terhadap Kuat Tarik Baja. 4(4), 371-379.

Singh, R. P., Gupta, R. C., \& Sarkar, S. C. 2012. The Effect of Process Parameters on Penetration in Shielded Metal Arc Welding under Magnetic Field using Artificial Neural Networks. International Journal of Application or Innovation in Engineering \& Management (IJAIEM). 1(4), 12-17.

Wardoyo, J. T. 2005. Metode Peningkatan Tegangan Tarik Dan Kekerasan Pada Baja Karbon Rendah Melalui Baja Fasa Ganda. 10(3). 237-248.

Wiryosumarto, H., \& Okumura, T. 2000. Teknologi Pengelasan Logam. Jakata: PT Pradnya Paramita. 